\title{
A NEW RECORD FOR NITIDULIDAE FAUNA OF TURKEY: SORONIA PUNCTATISSIMA (ILLIGER, 1794) (COLEOPTERA: NITIDULIDAE)
}

\author{
Inanç Özgen ${ }^{* 1}$, Aykut Topdemir ${ }^{1}$ \\ ${ }^{1}$ Firat University, Faculty of Engineering, Department of Bioengineering, Turkey
}

Abstract
In this study; a widespread nitidulid species Soronia punctatissima (Illiger, 1794) is reported for the first time from Turkey.)

\section{Introduction}

The Nitidulidae family is represented by around 4.000 species, which are included in the team of beetles (Coleoptera) and spread all over the world (Baviera \& Audisio, 2014, Anlaş and Özgen, 2018). In Turkey, 215 species belonging to five subfamilies in the family Nitidulidae are reported. (Avgin et al., 2015). As for the genus Soronia Erichson, 1843, four species were listed. Including this record, five species of this genus is known from Turkey The studied material from East Anatolia was collected in the year 2013 from a mountain area and its banks. The samples were collected by shifter on soil and they were preserved in $70 \%$ ethanol. Specimens were identified by Eduard Khachikov (Russia).

Soronia punctatissima (Illiger, 1794)

\section{Material examined}

Turkey: Elazığ, Sivrice, Hazarbaba Mountain, 29.V.2013, 11 exs, 2.225 m, leg. Khachikov \& Özgen.

\section{Distribution in world}

Austria, Belarus, Belgium, Bosnia and Herzegovina, Britain , Bulgaria, Central European Russia territory, Corsica, Crotia, Czech Republic, Denmark, East European Russia territory, Eastern Palearctic, Estonia, Finland, France, Germany, Hungary, Ireland, Italy, Latvia, Lithuania, Luxembourg, Moldova, Near East, North European Russia territory, Northern Ireland, Nortwest European Russia territory, Norway, Poland, Romania, Sardinia, Slovakia, Slovenia, South European Russia territory, Spain, Sweden, Switzerland, The
Netherlands, Ukraine, Yugoslavia (Jelínek \& Audisio, 2007).

In the future studies, the behavior of the species in the habitat should be determined.

\section{References}

Anlaş, S. and İ. Özgen, 2018. Türkiye Nitidulidae Faunasına Katkılar. Anadolu I. Uluslararası Multidisipliner Çalışmalar Kongresi, Tam Metin Kitabı, 28-29 Aralık, 2018, Diyarbakır. 967-969 s.

Baviera C. \& Audisio P. 2014. The Nitidulidae and Kateretidae (Coleoptera: Cucujoidea) of Sicily: Recent records and updated checklist. Atti della Accademia Peloritana dei Pericolanti Classe di Scienze Fisiche, Matematiche e Naturali, Vol. 92, No. 2, A1, 32 pp.

Avgın, S. S., Antonini, G., Lason, A., Jansson, N., Abacıgil, T.Ö., Varlı, S.V., Biase, A.D. and P. Audisio, 2015., New data on distribution, ecology, and taxonomy of Turkish Nitidulidae (Coleoptera). Turk J. Zool , 39: 314-322.

Jelínek J., Audisio P. (2007). Family Nitidulidae. In: Löbl I, Smetana A, editors. Catalogue of Palaearctic Coleoptera. Vol. 4: Elateroidea - Derodontoidea - Bostrichoidea Lymexyloidea - Cleroidea - Cucujoidea. Stenstrup, Denmark: Apollo Books, pp. 459-491. 